\title{
Satisfaction and attitudes of the student population about dental esthetics
}

\author{
Alma Gavranović-Glamoč ${ }^{*}$, Lejla Kazazić1, Sanela Strujić-Porović1, Emir Berhamović1, Amela Đonlagić1, \\ Selma Zukićz, Selma Jakupovićc ${ }^{3}$ Selma Tosum Pošković1
}

'Department of Prosthodontics, Faculty of Dentistry with Clinics, University of Sarajevo, Bosnia and Herzegovina, ${ }^{2}$ Department of Dental Morphology, Anthropology and Forensics, Faculty of Dentistry with Clinics, University of Sarajevo, Bosnia and Herzegovina, ${ }^{3}$ Department of Restorative Dentistry with Endodontics, Faculty of Dentistry with Clinics, University of Sarajevo, Bosnia and Herzegovina

\section{ABSTRACT}

Introduction: Perceptions of the esthetic appearance of teeth vary in different individuals and can affect satisfaction with the dental appearance, attitudes, and the need for appropriate dental treatment. The research aims to examine the factors influencing the satisfaction with the appearance of the dentition and the attitude toward treatments which improve dental esthetics among students of the faculty of dentistry in comparison to the attitudes of students of non-dental faculties.

Methods: The research included a total of 358 students of the Faculty of Dentistry and Faculty of Architecture in Sarajevo who voluntarily filled out a questionnaire created for this research. The questionnaire contained questions related to satisfaction with the appearance of teeth in general, tooth color, tooth position, questions related to the previous, and future desired esthetic restorations and treatments.

Results: Female subjects expressed statistically significantly greater dissatisfaction with the appearance of the dentition and did or plan to do treatments that could improve dental esthetics compared to male subjects. Students of the Faculty of Dentistry at final years were significantly more satisfied with the general appearance of teeth and tooth color compared to freshmen students of the Faculty of Dentistry and students of the Faculty of Architecture.

Conclusion: Satisfaction with dental appearance is a subjective experience that is influenced by various factors, level, and type of education is among them.

Keywords: Student's population; dental esthetic; satisfaction; desired esthetic treatment

\section{INTRODUCTION}

Esthetic dentistry can be defined as the process of achieving a natural and harmonious appearance using the highest standards (1), according to the preferences of the people involved.

Facial appearance is the most striking part of one's appearance. It is of special social and psychological significance for an individual, especially in communication and interaction with the environment (2).

In social interaction, attention is mainly focused on the mouth and eyes of the speaker, with eye and lip movements with teeth participating in the function of speech and expression as well as the creation of facial expressions (3).

Corresponding author: Alma Gavranović-Glamoč, Department of Prosthodontics, Faculty of Dentistry with Clinics, University of Sarajevo, Bosnia and Herzegovina, Bolnička 4a, Sarajevo, Bosnia and Herzegovina. Phone: +387 33 214-249, E-mail: alma.glamoc@gmail.com, ORCID ID: http://www.orcid.org/0000-0001-5232-868X

Submitted: 26 July 2021/Accepted: 08 November 2021
Since eyes, smile, and teeth are the most dominant part of the face, they are also the most important characteristics that determine the attractiveness of a person $(4,5)$.

From this aspect, the lower third of the face proved to be an extremely important factor in the perception of facial esthetics, and the beauty of the lower third of the face, and thus the entire face, was reduced to certain standards (6). These standards apply to the soft structures of the face and lips, the proportions of the face, the height of the lower third of the face, the position of the lips, the size, shape, position and color of the teeth, and the position, color, and shape of the gingiva $(7,8)$.

Frese et al. in their review paper announced that seven esthetically related parameters are objectively measurable: Smile line, lip line, incisal edge, the position of the dental and central line of the face, incisor inclination, width and height of the upper front teeth, gingival contour, coverage roots, and height of interdental papilla (9). All those parameters can be objectively measured, but the perception of the dental esthetic itself includes an important subjective component. 
Colored or worn teeth, damaged enamel, defective dental restorations, carious lesions, toothless spaces, can have serious consequences in terms of self-condemnation and negative attitudes of other people toward the individual. A lack of a proportionate and beautiful smile could affect a person's self-esteem as well as mental and physical health (10).

Having in mind the above, dentistry has begun to occupy a very important place in almost all spheres of human life. The interest of patients and dentists in esthetic dentistry has grown significantly in recent decades, probably due to the extremely large influence of modern media $(11,12)$.

The positive impact of a dental procedure on a patient's smile, appearance, self-esteem, overall mental health, satisfaction, and self-image is more than obvious. Esthetic procedures that achieve an attractive smile include the creation of dental restoration following the composition of the face (2). Imitation of the natural morphological characteristics of teeth harmonized with the appropriate soft-tissue architecture is the goal of every dentist. The patient's subjective perception of his appearance is influenced by numerous factors, mostly cultural, socio-demographic factors, and nowadays the exceptional importance of different types of media $(2,11,12)$.

Furthermore, the influence of factors such as the psychological profile of the individual, his character, age, gender, and level of education is unquestionable (13-16). Regarding education, not only the level of education but the type of education as well might influence the perception. Therefore, it seems interesting to evaluate the perception of dental esthetics in persons with an education in architecture due to their specific taste in art combined with technical sciences.

The previous studies worldwide conducted to evaluate satisfaction with dental esthetics have indicated a high percentage of dissatisfaction in humans. Individuals show varying degrees of sensitivity to certain esthetic issues, but in most studies, the greatest dissatisfaction was with the general appearance of the teeth, tooth color, poor front tooth alignment, and the presence of different restorations on the front teeth (10-20).

The assessment of dental appearance is mostly contributed by the six upper front teeth that are most visible during communication, function, and smile $(21,22)$. The assessment of the appearance of these six upper teeth is influenced by various factors such as color, shape, and size of teeth and the visibility of teeth and gums at rest and smiling. All of these factors can be considered individually, but ultimately, they must form a coherent whole.

In this paper, we will consider a number of significant factors that affect dental esthetics to improve it, as well as achieve adequate clinical results in patients. Recognizing patients' perceptions and their satisfaction with current dental appearance and desired treatments to improve dental esthetics can contribute to clinicians in a strategy of good clinical practice and achieving patient satisfaction.

The research aims to examine the factors that affect satisfaction with the appearance of dentition and attitudes toward treatments that affect the improvement of dental esthetics among dental students and to compare their attitudes with non-dental students. The type of education, dental versus non-dental might influence the perception of dental esthetics.

\section{METHODS}

A total of 358 students of the Faculty of Dentistry and of the Faculty of Architecture in Sarajevo were included in the research. All students voluntarily completed a questionnaire adopted from the research of Maghaireh et al. (23). The research was approved by the Ethics Committee of the Faculty of Dentistry at the University of Sarajevo.

The questionnaire contains general information about the respondent (age, gender, faculty, and year of study), questions about the frequency of visits to the dentist.

The part of the questionnaire related to satisfaction with dental appearance and esthetics contains ten questions on the satisfaction with the appearance of teeth in general, tooth color, tooth position, questions related to the previous esthetic restorations, and previous treatments (teeth whitening, orthodontic treatment, esthetic scales, or crowns), and questions for the desired treatment related to these parameters.

A total of 251 students were surveyed at the Faculty of Dentistry, 124 in the $2^{\text {nd }}$ year of study, 65 in the $5^{\text {th }}$ year, and 62 in the $6^{\text {th }}$ year of study. A total of 107 students were surveyed at the Faculty of Architecture, of which 57 were in the $1^{\text {st }}$ year and 50 in the $3^{\text {rd }}$ year of study. For this study, subjects were divided into three groups.

Students of the Faculty of Dentistry were divided into two groups to examine the influence of the level of dental education on the formation of attitudes about satisfaction with dental esthetics.

The first group comprised students of $5^{\text {th }}$ - and $6^{\text {th }}$-year of study of the faculty of dentistry.

The second group comprised $2^{\text {nd }}$-year students of the faculty of dentistry.

The third group consists of students of the Faculty of Architecture in the $1^{\text {st }}$ and $3^{\text {rd }}$ year, that is, students of the non-dental group.

Statistical analysis of the data was performed in IBM SPSS Statistics v.22. From the descriptive statistical methods, frequencies and percentages of modalities were calculated, as well as arithmetic means and corresponding standard deviations. Hypothesis testing was performed with a Student $t$-test of independent samples, Pearson's Chi-square test and Chi-square test with Yates continuity correction, as well as Kruskal-Wallis and Mann-Whitney nonparametric tests. The hypotheses were tested at the alpha level of $95 \%$, that is, the tested differences between the samples were recognized as statistically significant if the realized $p<5 \%$.

\section{RESULTS}

A total of 358 respondents surveyed at the Faculty of Dentistry and Architecture were included in the research. Table 1 shows the number of respondents in relation to the faculty and the $1^{\text {st }}$ year of study. Of the total number of respondents, $69.8 \%$ were women, while $30.2 \%$ were men.

In the analysis of variables between the sexes of the respondents, the answers of the respondents were expressed on 
TABLE 1. Number of respondents in relation to the faculty and year of study

\begin{tabular}{lccccc}
\hline & \multicolumn{4}{c}{ College } \\
\cline { 2 - 3 } \cline { 5 - 6 } & \multicolumn{2}{c}{ Dentistry } & & \multicolumn{2}{c}{ Architecture } \\
\cline { 2 - 3 } \cline { 5 - 6 } Year of study & Count & & & Count & $\%$ \\
I. & 0 & 0.0 & & 57 & 53.3 \\
II. & 124 & 49.4 & & 0 & 0.0 \\
III. & 0 & 0.0 & & 50 & 46.7 \\
V. & 65 & 25.9 & & 0 & 0.0 \\
VI. & 62 & 24.7 & & 0 & 0.0 \\
Total & 251 & 100 & & 107 & 100 \\
\hline
\end{tabular}

categorical scales of the nominal type, so the Chi-square independence test was used as a statistical method. Hypotheses were tested at the alpha level of $95 \%$, that is, with $5 \%$ risk. Female subjects expressed a statistically significantly higher dissatisfaction with the general appearance of teeth $(p<0.021)$ and tooth color $(p<0.002)$ compared to male subjects $(p<0.021)$. (Table 2) Female subjects in a significantly higher percentage had previously done orthodontic treatment $(p<0.004)$ and replaced the existing fillings with those in tooth color $(p<0.003)$. When it comes to expressed desires for different dental treatments that improve esthetics, women in a statistically significantly higher percentage express the intention to whiten teeth $(p<0.003)$ and undergo orthodontic treatment $(p<0.013)$ compared to men (Table 2).

In the analysis of variables between different groups of respondents from statistical methods, both the Chi-square test on nominal variables and the Kruskal-Wallis test on variables of ordinal (rank) type was used. Subjects from the first group $\left(5^{\text {th }}\right.$ and $6^{\text {th }}$-year students of the Faculty of Dentistry) are significantly more satisfied with the general appearance of teeth $(p<0.043)$ compared to the second group ( $2^{\text {nd }}$-year students of the Faculty of Dentistry) and the third group of respondents (students of the Faculty of Architecture) (Table 3).

Furthermore, respondents from the first group significantly more often show satisfaction with the color of their teeth compared to respondents from the second and third groups $(p<0.004)$ (Table 3).

The desire for the treatment of teeth whitening in a significantly higher percentage is expressed by subjects from the second and third groups than by subjects from the first $(p<0.000)$ (Table 3). Statistically, a significantly higher percentage of subjects from the third group had problems with caries of front teeth than respondents from the first and second groups $(p<0.000)$ (Table 3).

The study of the relationship between the attitudes of all respondents regardless of age, gender, and study year (level of education) about the dental appearance and esthetics of the teeth and the attitudes toward the previous and future treatment of the teeth was conducted by Chi-square test with a risk of $5 \%$. Our results indicate that teeth whitening would be significantly more often done by persons who are not satisfied with the color of their teeth $(p<0.000)$ (Table 4).

Orthodontic treatment would be significantly more often performed by persons who are dissatisfied with the general appearance of teeth $(p<0.000)$, than persons who are not satisfied with tooth color $(p<0.001)$, persons who consider their front teeth to be compacted $(p<0.000)$, and persons who consider that their teeth are poorly aligned $(p<0.000)$ (Table 4).

Crowns or veneers would be requested significantly more often by people who are not satisfied with the general appearance of teeth $(p<0.002)$, who are not satisfied with the color of teeth $(p<0.017)$, people who think their teeth are spaced $(p<0.006)$, people who think that their teeth were poorly aligned $(p<0.007)$, persons who had some esthetic restorations on the front teeth $(p<0.000)$, as well as persons who more often hid their teeth when laughing $(p<0.036)$.

The desire to replace the filling in a significantly higher percentage is expressed by respondents who are dissatisfied with the appearance $(p<0.017)$ and tooth color $(p<0.009)$, than respondents who believe that their front teeth are tight $(p<0.025)$, as well as those respondents who a larger percentage believe that their teeth are poorly aligned $(p<0.048)$ Table 4.

Those persons who bleached their teeth in a statistically significantly higher percentage hide them when they laugh $(p<0.016)$.

Subjects who replaced existing fillings with tooth-colored ones in a statistically significantly higher percentage and hid their teeth when laughing, while subjects who did not perform such treatment in a significantly higher percentage did not hide their teeth when laughing $(p<0.017)$.

\section{DISCUSSION}

Gender differences play an important role in satisfaction with dental appearance given that men and women have different requirements and needs in tooth appearance, so it is assumed that in assessing the appearance of their teeth using different parameters. In our study, female subjects showed a statistically significantly higher dissatisfaction with the general appearance of teeth $(p<0.021)$ and tooth color $(p<0.002)$, compared to male subjects. We can relate these results to the fact that females are more interested in their appearance than men, notice certain details more, and judge their appearance more critically (24).

This behavior is also confirmed by women's increased self-awareness when it comes to beauty and fashion compared to men.

In study conducted by Bilal in Saudi Arabia and Silva GC in Brazil among the student population of dental colleges female students had a desire to have a smile as celebrities while being more updated with the latest issues of fashion magazines and blogs (24-26).

Our results are in agreement with the results of Strajnic et al., Tin-Oo et al., where greater dissatisfaction with tooth color and general tooth appearance was shown by females compared to male respondents $(19,27)$. In a study by Akarslan et al. From Turkey, female respondents showed greater dissatisfaction with the general appearance of teeth compared to male ones, but it was not statistically significant (12). Al-Saleh et al. and associates at the University of Riyadh in their study aimed at assessing the esthetic 
TABLE 2. Relation between satisfaction with dental esthetics, types of existing treatments, and desired dental treatments with the gender of the respondents

\begin{tabular}{|c|c|c|c|c|c|c|}
\hline & \multicolumn{6}{|c|}{ Sex } \\
\hline & \multicolumn{2}{|c|}{ Male } & \multicolumn{2}{|c|}{ Female } & \multirow[t]{2}{*}{ Chi-square* $^{*}$} & \multirow[t]{2}{*}{$p$} \\
\hline & $n$ & $\%$ & $n$ & $\%$ & & \\
\hline \multicolumn{7}{|c|}{ Are you happy with the look of your teeth in general? } \\
\hline No & 15 & 19.7 & 61 & 80.3 & 5.35 & 0.021 \\
\hline Yes & 93 & 33.5 & 185 & 66.5 & & \\
\hline \multicolumn{7}{|c|}{ Are you happy with the color of your teeth? } \\
\hline No & 22 & 19.3 & 92 & 80.7 & 9.87 & 0.002 \\
\hline Yes & 86 & 35.8 & 154 & 64.2 & & \\
\hline \multicolumn{7}{|c|}{ Do you think your front teeth are crowded? } \\
\hline No & 81 & 31.2 & 179 & 68.8 & 0.091 & 0.762 \\
\hline Yes & 27 & 28.7 & 67 & 71.3 & & \\
\hline \multicolumn{7}{|c|}{ Do you feel that your teeth are too much spaced apart? } \\
\hline No & 99 & 31.5 & 215 & 68.5 & 1.076 & 0.300 \\
\hline Yes & 9 & 22.5 & 31 & 77.5 & & \\
\hline \multicolumn{7}{|c|}{ Do you think your teeth are poorly aligned? } \\
\hline No & 84 & 33.5 & 167 & 66.5 & 3.040 & 0.081 \\
\hline Yes & 24 & 23.3 & 79 & 76.7 & & \\
\hline \multicolumn{7}{|c|}{ Do you have caries on your front teeth? } \\
\hline No & 102 & 30.6 & 231 & 69.4 & 0.004 & 0.948 \\
\hline Yes & 6 & 28.6 & 15 & 71.4 & & \\
\hline \multicolumn{7}{|c|}{ Do you have any esthetic restorations on your front teeth? } \\
\hline No & 90 & 31.1 & 199 & 68.9 & 0.457 & 0.499 \\
\hline Yes & 18 & 27.7 & 47 & 72.3 & & \\
\hline \multicolumn{7}{|c|}{ Do you hide your teeth when you laugh? } \\
\hline No & 91 & 29.9 & 213 & 70.1 & 0.135 & 0.713 \\
\hline Yes & 17 & 34.0 & 33 & 66.0 & & \\
\hline \multicolumn{7}{|c|}{ Have you ever done a teeth whitening treatment? } \\
\hline No & 98 & 30.2 & 226 & 69.8 & 0.000 & 1.000 \\
\hline Yes & 10 & 29.4 & 24 & 70.6 & & \\
\hline \multicolumn{7}{|c|}{ Have you done orthodontics treatment? } \\
\hline No & 74 & 36.5 & 129 & 63.5 & 8.118 & 0.004 \\
\hline Yes & 34 & 21.9 & 121 & 78.1 & & \\
\hline \multicolumn{7}{|c|}{ Did you make crowns or veneers? } \\
\hline No & 102 & 30.5 & 232 & 69.5 & 0.116 & 0.733 \\
\hline Yes & 6 & 25.0 & 18 & 75.0 & & \\
\hline \multicolumn{7}{|c|}{ Have you replaced existing filling with esthetic filling? } \\
\hline No & 88 & 35.2 & 162 & 64.8 & 8.911 & 0.003 \\
\hline Yes & 20 & 18.7 & 87 & 81.3 & & \\
\hline \multicolumn{7}{|c|}{$\begin{array}{l}\text { Would you improve the esthetics of your teeth with tooth } \\
\text { whitening treatment? }\end{array}$} \\
\hline No & 62 & 38.3 & 100 & 61.7 & 8.535 & 0.003 \\
\hline Yes & 46 & 23.5 & 150 & 76.5 & & \\
\hline \multicolumn{7}{|c|}{$\begin{array}{l}\text { Would you improve the esthetics of your teeth with } \\
\text { orthodontic treatment? }\end{array}$} \\
\hline No & 68 & 36.2 & 120 & 63.8 & 6.185 & 0.013 \\
\hline Yes & 40 & 23.5 & 130 & 76.5 & & \\
\hline \multicolumn{7}{|c|}{$\begin{array}{l}\text { Would you improve the esthetics of your teeth by making } \\
\text { crowns or veneers? }\end{array}$} \\
\hline No & 84 & 29.8 & 198 & 70.2 & 0.026 & 0.872 \\
\hline Yes & 24 & 31.6 & 52 & 68.4 & & \\
\hline $\begin{array}{l}\text { Would } \\
\text { old colc }\end{array}$ & & & & & & \\
\hline No & 75 & 30.6 & 170 & 69.4 & 0.071 & 0.790 \\
\hline Yes & 32 & 28.6 & 80 & 71.4 & & \\
\hline
\end{tabular}

perception of smiles in dental students confirmed a significant gender impact in which female students showed more dissatisfaction than male students with their smiles (28).
The results in examining the relationship between gender and frequency of visits to the dentist in our study also showed that females visited the dentist more often and 
TABLE 3. Relation between satisfaction with dental esthetics. types of existing treatments and desired dental treatments

\begin{tabular}{|c|c|c|c|c|c|c|c|c|}
\hline & \multicolumn{8}{|c|}{ A group of respondents } \\
\hline & \multicolumn{2}{|c|}{ I. Group } & \multicolumn{2}{|c|}{ II. Group } & \multicolumn{2}{|c|}{ III. Group } & \multirow[t]{2}{*}{ Chi-square* $^{*}$} & \multirow[t]{2}{*}{$p$} \\
\hline & $n$ & $\%$ & $n$ & $\%$ & $n$ & $\%$ & & \\
\hline \multicolumn{9}{|c|}{ Are you happy with the look of your teeth in general? } \\
\hline No & 19 & 24.1 & 30 & 38.0 & 30 & 38.0 & 6.273 & 0.043 \\
\hline Yes & 108 & 38.7 & 94 & 33.7 & 77 & 27.6 & & \\
\hline \multicolumn{9}{|c|}{ Are you happy with the color of your teeth? } \\
\hline No & 30 & 25.6 & 40 & 34.2 & 47 & 40.2 & 10.896 & 0.004 \\
\hline Yes & 97 & 40.2 & 84 & 34.9 & 60 & 24.9 & & \\
\hline \multicolumn{9}{|c|}{ Do you think your front teeth are crowded? } \\
\hline No & 90 & 34.2 & 95 & 36.1 & 78 & 29.7 & 1.088 & 0.580 \\
\hline Yes & 37 & 38.9 & 29 & 30.5 & 29 & 30.5 & & \\
\hline \multicolumn{9}{|c|}{ Do you feel that your teeth are too much spaced apart? } \\
\hline No & 113 & 35.6 & 113 & 35.6 & 91 & 28.7 & 2.131 & 0.345 \\
\hline Yes & 14 & 34.1 & 11 & 26.8 & 16 & 39.0 & & \\
\hline \multicolumn{9}{|c|}{ Do you think your teeth are poorly aligned? } \\
\hline No & 93 & 36.6 & 92 & 36.2 & 69 & 27.2 & 3.122 & 0.210 \\
\hline Yes & 34 & 32.7 & 32 & 30.8 & 38 & 36.5 & & \\
\hline \multicolumn{9}{|c|}{ Do you have caries on your front teeth? } \\
\hline No & 125 & 37.2 & 120 & 35.7 & 91 & 27.1 & 20.825 & 0.000 \\
\hline Yes & 2 & 9.1 & 4 & 18.2 & 16 & 72.7 & & \\
\hline \multicolumn{9}{|c|}{ Do you have any esthetic restorations on your front teeth? } \\
\hline No & 100 & 34.6 & 101 & 34.9 & 88 & 30.4 & 0.522 & 0.770 \\
\hline Yes & 27 & 39.1 & 23 & 33.3 & 19 & 27.5 & & \\
\hline \multicolumn{9}{|c|}{ Do you hide your teeth when you laugh? } \\
\hline No & 115 & 37.5 & 102 & 33.2 & 90 & 29.3 & 3.869 & 0.144 \\
\hline Yes & 12 & 23.5 & 22 & 43.1 & 17 & 33.3 & & \\
\hline \multicolumn{9}{|c|}{ Have you ever done a teeth whitening treatment? } \\
\hline No & 117 & 36.1 & 107 & 33.0 & 100 & 30.9 & 4.036 & 0.133 \\
\hline Yes & 10 & 29.4 & 17 & 50.0 & 7 & 20.6 & & \\
\hline \multicolumn{9}{|c|}{ Have you done orthodontics treatment? } \\
\hline No & 67 & 33.0 & 65 & 32.0 & 71 & 35.0 & 5.793 & 0.055 \\
\hline Yes & 60 & 38.7 & 59 & 38.1 & 36 & 23.2 & & \\
\hline \multicolumn{9}{|c|}{ Did you make crowns or veneers? } \\
\hline No & 117 & 35.0 & 118 & 35.3 & 99 & 29.6 & 1.070 & 0.586 \\
\hline Yes & 10 & 41.7 & 6 & 25.0 & 8 & 33.0 & & \\
\hline \multicolumn{9}{|c|}{ Did you change your existing fillings with esthetic filings? } \\
\hline No & 88 & 35.2 & 84 & 33.6 & 78 & 31.2 & 0.629 & 0.730 \\
\hline Yes & 39 & 36.4 & 39 & 36.4 & 29 & 27.1 & & \\
\hline \multicolumn{9}{|c|}{$\begin{array}{l}\text { Would you improve the esthetics of your tooth teeth } \\
\text { whitening treatment? }\end{array}$} \\
\hline No & 77 & 47.5 & 48 & 29.6 & 37 & 22.8 & 19.184 & 0.000 \\
\hline Yes & 50 & 25.5 & 76 & 38.8 & 70 & 35.7 & & \\
\hline $\begin{array}{l}\text { Would i } \\
\text { treatme }\end{array}$ & & & & & & & & \\
\hline No & 67 & 35.5 & 61 & 32.4 & 60 & 31.9 & 1.095 & 0.578 \\
\hline Yes & 60 & 35.3 & 63 & 37.1 & 47 & 27.6 & & \\
\hline $\begin{array}{l}\text { Would i } \\
\text { veneers }\end{array}$ & & & & & & & & \\
\hline No & 101 & 35.8 & 95 & 33.7 & 86 & 30.5 & 0.553 & 0.758 \\
\hline Yes & 26 & 34.2 & 29 & 38.2 & 21 & 27.6 & & \\
\hline $\begin{array}{l}\text { Would } \\
\text { colored }\end{array}$ & & & & & & & & \\
\hline No & 87 & 35.5 & 80 & 32.7 & 78 & 31.8 & 1.642 & 0.440 \\
\hline Yes & 40 & 35.7 & 43 & 38.4 & 29 & 25.9 & & \\
\hline
\end{tabular}

*Pearson Chi-Square

that they did significantly more orthodontic treatment $(p<0.004)$ and replaced existing fillings with those in tooth color $(p<0.003)$, in comparison to male respondents.
Given that dissatisfaction with the appearance of teeth is significantly associated with poor tooth position and poor tooth color, female persons significantly 
TABLE 4. Relationship between satisfaction with dental esthetics and desire for appropriate esthetic treatment

\begin{tabular}{|c|c|c|c|c|c|c|}
\hline & \multicolumn{6}{|c|}{ Would you do teeth whitening? } \\
\hline & \multicolumn{2}{|c|}{ No } & \multicolumn{4}{|c|}{ Yes } \\
\hline & \multicolumn{2}{|c|}{$n$} & \multicolumn{2}{|l|}{$n$} & Chi-square* $^{*}$ & $p$ \\
\hline \multicolumn{7}{|c|}{ Are you happy with the color of your teeth? } \\
\hline No & 28 & 23.9 & 89 & 76.1 & 30.621 & 0.000 \\
\hline \multirow[t]{4}{*}{ Yes } & 134 & 55.6 & 107 & 44.4 & & \\
\hline & \multicolumn{6}{|c|}{ Would you do orthodontic treatment? } \\
\hline & \multicolumn{2}{|c|}{ No } & \multicolumn{4}{|c|}{ Yes } \\
\hline & $n$ & $\%$ & $n$ & $\%$ & Chi-square $^{*}$ & $p$ \\
\hline \multicolumn{7}{|c|}{ Are you happy with the look of your teeth in general? } \\
\hline No & 21 & 26.6 & 58 & 73.4 & \multirow[t]{2}{*}{26.017} & \multirow[t]{2}{*}{0.000} \\
\hline Yes & 167 & 59.9 & 112 & 40.1 & & \\
\hline \multicolumn{7}{|c|}{ Are you happy with the color of your teeth? } \\
\hline No & 46 & 39.3 & 71 & 60.7 & \multirow[t]{2}{*}{11.366} & 0.001 \\
\hline Yes & 142 & 58.9 & 99 & 41.1 & & \\
\hline Do you & & & & & & \\
\hline No & 161 & 61.2 & 102 & 38.8 & 28.801 & 0.000 \\
\hline Yes & 27 & 28.4 & 68 & 71.6 & & \\
\hline Do you & & & & & & \\
\hline No & 162 & 63.8 & 92 & 36.2 & 42.957 & 0.000 \\
\hline Yes & 26 & 25.0 & 78 & 75.0 & & \\
\hline & & Wo & make & רs or v & (esthetic)? & \\
\hline & & & & & Yes & \\
\hline & $n$ & $\%$ & $n$ & $\%$ & Chi-square* $^{*}$ & $p$ \\
\hline Are you & & & & & & \\
\hline No & 52 & 65.8 & 27 & 34.2 & 9.194 & 0.002 \\
\hline Yes & 230 & 82.4 & 49 & 17.6 & & \\
\hline Are you & & & & & & \\
\hline No & 83 & 70.9 & 34 & 29.1 & 5.697 & 0.017 \\
\hline Yes & 199 & 82.6 & 42 & 17.4 & & \\
\hline Do you & & & & & & \\
\hline No & 257 & 81.1 & 60 & 18.9 & 7.608 & 0.006 \\
\hline Yes & 25 & 61.0 & 16 & 39.0 & & \\
\hline Do you & & & & & & \\
\hline No & 210 & 82.7 & 44 & 17.3 & 7.194 & 0.007 \\
\hline Yes & 72 & 69.2 & 32 & 30.8 & & \\
\hline Do you & & & & & & \\
\hline No & 244 & 84.4 & 45 & 15.6 & 26.978 & 0.000 \\
\hline Yes & 38 & 55.1 & 31 & 44.9 & & \\
\hline Do you & & & & & & \\
\hline No & 248 & 80.8 & 59 & 19.2 & 4.401 & 0.036 \\
\hline Yes & 34 & 66.7 & 17 & 33.3 & & \\
\hline & & uld you & sting $f$ & replace & tooth-colored o & \\
\hline & & & & & Yes & \\
\hline & $n$ & $\%$ & $n$ & $\%$ & Chi-square* & $p$ \\
\hline Are you & & & & & & \\
\hline No & 45 & 57.0 & 34 & 43.0 & 5.735 & 0.017 \\
\hline Yes & 200 & 71.9 & 78 & 28.1 & & \\
\hline Are you & & & & & & \\
\hline No & 69 & 59.0 & 48 & 41.0 & 6.880 & 0.009 \\
\hline Yes & 176 & 73.3 & 64 & 26.7 & & \\
\hline Do you & & & & & & \\
\hline No & 189 & 72.1 & 73 & 27.9 & 5.038 & 0.025 \\
\hline Yes & 56 & 58.9 & 39 & 41.1 & & \\
\hline Do you & & & & & & \\
\hline No & 182 & 71.9 & 71 & 28.1 & 3.906 & 0.048 \\
\hline Yes & 63 & 60.6 & 41 & 39.4 & & \\
\hline
\end{tabular}

${ }^{*}$ Continuity Correction

wanted to undergo orthodontic treatment $(p<0.013)$ and teeth whitening $(p<0.003)$ compared to male subjects, which is according to research by Armalaite and associates who conducted a study at the Lithuanian University of Health Sciences that aimed to assess how characteristics of a smile are experienced by dental students. In the study, women were significantly more critical than men in assessing smiles, the "golden proportion," dental crowding, and occlusal cant (29). According to Wolfart et al., satisfaction with 
the appearance of the anterior incisors according to the gold standard was higher for men than for women (30).

In our study conducted by Maghaireh et al., there was a significantly higher number of women who had esthetic restorations and orthodontic treatment $(p=0.008,0.000)$ and wanted the same treatments again (23).

In various studies, it is evident that age affects satisfaction with dental appearance $(12,17,23,31)$. Older people tend to be more satisfied with dental appearance than young people, who put more emphasis on external appearance than older people. Adolescence is a transformational phase when various physical changes occur, then changes in one's attitudes and self-confidence. The adolescent must achieve several emotional or developmental milestones before becoming a psychologically mature individual (32).

The ability to adapt during this period is lower, which may be the reason why young people have greater insecurity and desire to change their appearance, and thus change the appearance of teeth.

This is confirmed by the results of our research where $2^{\text {nd }}$-year students of the Faculty of Dentistry showed greater dissatisfaction with appearance and color, as well as a greater desire for teeth whitening treatment compared to $5^{\text {th }}$ - and $6^{\text {th }}$-year students.

In a study by Alkhatib et al. and associates, respondents over the age of 55 were more satisfied with the appearance of their teeth compared to younger ones. This is confirmed by Grzić et al. and associates, who add that this finding is greatly influenced by dental status, which changes with age (31). On the other hand, Al-Zarea and Tin-Oo et al. did not confirm the influence of age on dental appearance satisfaction $(19,33)$.

Young people have a greater tendency for lighter teeth, which has been shown in our research. This may be related to the fact that young people are heavily influenced by the media and the environment, trying to look prettier and healthier, knowing that there is a strong link between appearance and social status, as evidenced by better jobs and social acceptability.

The study by Larsson showed that younger patients from the general population considered tooth color to be the most important factor in assessing the appearance of their teeth (34).

A study by Kershaw et al. showed that subjects with whiter teeth were more satisfied with the appearance of their teeth and that tooth color was one of the most important factors of social status (35).

Greater dissatisfaction with dental appearance or color at a young age may indicate that perceived appearance is more related to cognitive than social and cultural factors (31). These data are the result of education levels because $5^{\text {th }}$ and $6^{\text {th }}$-year students of the Faculty of Dentistry who have a higher level of education showed greater satisfaction with the general appearance of teeth $(p<0.043)$ and tooth color $(p<0.004)$ compared to $2^{\text {nd }}-$ year students of the Faculty of Dentistry and the Faculty of Architecture. We can summarize that these results are caused by higher maturity in general as well as better knowledge of the subject, that is, a higher level of dental education by older students. Students of the $5^{\text {th }}$ and $6^{\text {th }}$ year of the faculty perform clinical practice so that they can be considered much more competent compared to students of the $1^{\text {st }}$ and $2^{\text {nd }}$ years who we consider to be laymen in that matter. The same could be considered for non-dental students. Students of the Faculty of Architecture showed similar results on satisfaction with dental esthetics as dental students of the $1^{\text {st }}$ and $2^{\text {nd }}$ years. Nevertheless, they still lack better knowledge on the matter, especially on limits and possibilities of the improvement of dental esthetics. Our results are consistent with the results of Bilal (26) and El Mourad et al. (36) who conducted similar research in Saudi Arabia as well as the results of Silva et al. from Brazil who found a greater desire for white teeth among $1^{\text {st }}$ - and $2^{\text {nd }}$-year undergraduate students from older years. Hence, we can see how the perception of esthetics smiles changes over the years of professional development, that is, through the process of becoming a dentist, as confirmed by Al-Saleh et al. (28) and Althagafi (37), in their researches.

Armalaite et al. conducted the study only among senior students, so it is impossible to compare their results from that aspect with ours (29).

Raising awareness of the importance of dental esthetics and patients' interest in the appearance of the face and teeth are the reason for the demand for teeth whitening treatments, making crowns or veneers, replacement of tooth-colored fillings, or orthodontic treatment. In our research, we also examined the relationship between the attitudes of the respondents about the dental appearance and esthetics of the teeth and the attitudes towards previous and future dental treatment. The realized results of the analyzes show that those persons who were not satisfied with the color of their teeth showed a significantly higher desire for the treatment of teeth whitening $(p<0.000)$. In general, there is a tendency for white teeth that are associated with high grades of social competence, intellectual ability, psychological adjustment, and interpersonal relationships (35). Our results confirm the fact that tooth color satisfaction significantly affects tooth satisfaction and coincide with studies by other authors in which one of the basic treatments to improve dental esthetics was tooth whitening treatment $(12,16-19,33)$.

This can be explained by the fact that most patients were not satisfied with the color of their teeth, and many of them had not made any attempt at whitening in the past. Before performing the whitening treatment itself, the dentist must make a treatment plan and present to the patient the possibilities of this treatment so that it does not collide with the patient's expectations $(38,39)$.

Dissatisfaction with the appearance of teeth is often associated with poor tooth position in a row, so people who are not satisfied with the general appearance of teeth $(p<0.000)$, most often consider their front teeth to be compact $(p<0.000)$ or poorly aligned $(p<0.000)$. They also, in significantly more cases, had a desire for orthodontic treatment. In modern society, malocclusion affecting oral health is becoming more prevalent given the consequences that affect several aspects of quality of life, such as appearance, function, personal and social relationships, and psychological aspects $(40,41)$. The authors of numerous similar researches agree with our results $(17,33,42-44)$. There is generally a consensus that people are motivated 
to seek orthodontic treatment to improve the esthetics and negative physical, psychological, and social impacts of malocclusions (45-47). When planning orthodontic therapy, in addition to the specialist assessment of malocclusion, it is necessary to take into account the subjective needs, that is, the esthetic perception of the patient. Technological progress through the application of new materials and methods has enabled significant advances in prosthetic rehabilitation, which occupies a significant place in cosmetic dentistry aimed at achieving patient satisfaction with their smile (48-50). One should have in mind that prosthetic treatments are financially challenged, so the socio-economic status of the patient might influence the final therapy choice. Persons with lower socio-economic status might face difficulties in perusing sophisticated cosmetic dental treatments (51). Due to digital media there is a better knowledge of the type of esthetic requirements and possibilities of esthetic dental treatments among patients (52). Therefore, the result of our study that crowns or veneers would be significantly more often required by people who are not satisfied with the general appearance of teeth $(p<0.002)$, people who are not satisfied with tooth color $(p<0.017)$, people who think their teeth are spaced $(p<0.006)$, persons who had some esthetic restorations on the front teeth $(p<0.000)$, as well as persons who more often hid their teeth when laughing $(p<0.036)$. People who are less satisfied with the appearance of their teeth are more often exposed to esthetic dental treatments. The limitation of this study is that only persons with a certain knowledge of esthetics were included in our study, regardless of the level of the knowledge. Further research should include people without higher education levels and of different socio-economic statuses. The dental appearance of the patient today is one of the most important factors of facial appearance, and assessment of dental appearance and esthetics is a challenge, because they cannot be directly measured, and many factors, most culturally affect the patient's subjective perception of appearance. Until recently, the primary goal of dental prosthetic treatment was to establish the masticatory function; however, the need for a more beautiful appearance is now considered more important than any other indication requiring prosthetic treatment (53). Comparing the results of our research with studies of similar or the same content, we found significant coincidences regarding the desired esthetic treatment with the studies of Akarslan et al., Grzić et al., Tin-Oo et al., and Maghaireh et al. as significant differences, and based on that we have singled out the most important factors that should be taken into account during the esthetic procedure on the teeth of patients $(12,17,19,23)$. Esthetic conception is abstract and subjective; therefore, the formulation of a specific treatment goal and good communication between dentists and patients is crucial (15). Therefore, before starting therapy, it is important to find out all the patient's expectations regarding the proposed dental procedure, and sometimes it is necessary to find a compromise between the dentist's opinion and the patient's opinion, which is not always consistent $(54,55)$.

The need for beauty has existed since the existence of human society, hence the interest in esthetics, which is becoming increasingly dominant in modern society. Esthetic dentistry is aimed at achieving patient satisfaction with their appearance, and first with a smile (2).
Patient satisfaction and its perception of esthetics are becoming increasingly important factors in dental treatment, and the formulation of a specific goal of treatment and good communication between dentists and patients is of great importance.

Achieving the best possible esthetic results, including both natural and functional harmony, will be the result of coming together of the patients' cognition, dentists' diagnoses, and the expertise of dental technical associates.

\section{CONCLUSION}

Satisfaction with dental appearance is a subjective experience that is influenced by various factors. Such as culture, time, social norms, individual characteristics of an individual such as age, gender, and level of education affect the perception of an individual's appearance.

Understanding and respecting the individual needs and attitudes of the patient in relation to the existing state of dental esthetics and the desired treatment are important in the strategy of achieving function and optimal esthetic results. Regarding the limitation of this study further research with persons of different socioeconomic statuses and without specific education levels could provide additional information on a subjective perception of dental esthetics. This information could be used in finding a new approach in the promotion of specific esthetic dental treatments.

\section{ACKNOWLEDGMENTS}

The authors would like to thank all students who participated in this study.

\section{DECLARATION OF INTERESTS}

Authors declare no conflict of interest.

\section{REFERENCES}

1. Karthik KVGC, Padmaja BI, Babu NS, Haritha J, Nikhil M, Priya KS. Evaluation of esthetics of incisor position in relation to incisive papilla to replicate in the denture prosthesis. J Family Med Prim Care. 2020;9(1):298-302.

2. Gurel G. The Science and Art of Porcelain Laminate Veneers. $1^{\text {st }}$ ed. London, Chicago, Berlin: Quintessence Publishing; 2003.

3. Thompson L, Malmberg J, Goodell N, Boring R. The distribution of attention across a talker's face. Discourse Process 2004;38:145-68. https://doi.org/10.1207/s15326950dp3801_6

4. Kaipainen AE, Sieber KR, Nada RM, Maal TJ, Katsaros C, Fudalej PS. Regional facial asymmetries and attractiveness of the face. Eur J Orthod 2016;38(6):602-8. https://doi.org/10.1093/ejo/cjv087

5. Flores-Mir C, Silva E, Barriga MI, Lagravere MO, Major PW. Lay person's perception of smile aesthetics in dental and facial views. J Orthod 2004;31(3):204-9. https://doi.org/10.1179/146531204225022416

6. Mack MR. Perspective of facial esthetics in dental treatment planning. J Prosthet Dent 1996;75:169-76.

https://doi.org/10.1016/s0022-3913(96)90095-5

7. Duarte S Jr., Schnider P, Lorezon AP. The importance of width/length ratios of maxillary anterior permanent teeth in esthetic rehabilitation. Eur J Esthet Dent 2008;3(3):224-34.

8. van der Geld P, Oosterveld P, van Heck G, Kuijpers-Jagtman AM. Smile attractiveness. Self-perception and influence on personality. Angle Orthod 2007;77(5):759-65. https://doi.org/10.2319/082606-349

9. Frese $C$, Staehle $H J$, Wolff $D$. The assessment of dentofacial esthetics in restorative dentistry: A review of the literature. Am Dent Assoc 2012;143(5):461-6. https://doi.org/10.14219/jada.archive.2012.0205

10. Boeira GF, Salas MM, Araújo DC, Masotti AS, Correa MB, Demarco FF. Factors influencing dental appearance satisfaction in adolescents: A cross-sectional study conducted in Southern Brazil. Braz J Oral Sci 2016;15(1):8-15. 
11. Theobald AH, Wong BK, Quick AN, Thomson WM. The impact of the popular media on cosmetic dentistry. N Z Dent J 2006;102(3):58-63.

12. Akarslan Z, Sadik B, Erten H, Karabulut E. Dental esthetic satisfaction received and desired dental treatment for improvement of aesthetic. Indian J Dent Res 2009:20(2):195-200.

https://doi.org/10.4103/0970-9290.52902

13. Mehl CJ, Harder S, Kern M, Wolfart S. Patients' and dentists' perception of dental appearance. Clin Oral Investig 2011;15(2):193-9. https://doi.org/10.1007/s00784-010-0393-y

14. Vallittu PK, Vallittu AS, Lassila VP. Dental aesthetics: A survey of attitudes in different groups of patients. J Dent 1996;24(5):335-8.

https://doi.org/10.1016/0300-5712(95)00079-8

15. Mursid S, Maharani DA, Kusdhany L. Measuring patient's orofacial estheticsin in prosthodontics: A scoping review of a current instrument. Open Dent J 2020;14:161-70.

16. Samorodnitzky-Naveh GR, Geiger SB, Levin L. Patients' satisfaction with dental esthetics. J Am Dent Assoc 2007;138(6):805-8.

https://doi.org/10.14219/jada.archive.2007.0269

17. Grzić R, Spalj S, Lajnert V, Glavicić S, Uhac I, Pavicić DK. Factors influencing a patient's decision to choose the type of treatment to improve dental esthetics. Vojnosanit Pregl 2012;69(11):978-85.

18. Xiao J, Zhou X, Zhu W, Zhang B, Li J, Xu X. The prevalence of tooth discolouration and the self-satisfaction with tooth colour in a Chinese urban population. $J$ Ora Rehabil 2007;34(5):351-60 https://doi.org/10.1111/j.1365-2842.2007.01729.x

19. Tin-Oo M, Saddki N, Hassan N. Factors influencing patient satisfaction with dental appearance and treatments they desire to improve aesthetics. BMC Oral Health 2011;11:6. https://doi.org/10.1186/1472-6831-11-6

20. Silvola AS, Varimo M, Tolvanen M, Rusanen J, Lahti S, Pirttiniemi P. Dental esthetics and quality of life in adults with severe malocclusion before and after treatment. Angle Orthod 2014;84(4):594-9. https://doi.org/10.2319/060213-417.1

21. Spear FM, Kokich VG, Matthews DP. Interdisciplinary management of anterior dental esthetics. J Am Dent Assoc 2006;137(2):160-9. https://doi.org/10.14219/jada.archive.2006.0140

22. Peršić S. Utjecaj Estetskog i Funkcijskog Aspekta Protetske Terapije na Kvalitetu Života Ovisnu o Oralnom Zdravlju. Doktorski Rad: Stomatološki Fakultet Sveučilište u Zagrebu; 2014.

23. Maghaireh GA, Alzraikat $H$, Taha NA. Satisfaction with dental appearance and attitude toward improving dental esthetics among patients attending a dental teaching center. J Contemp Dent Pract 2016;17(1):16-21.

https://doi.org/10.5005/jp-journals-10024-1796

24. Hassel A, Wegener I, Rolko C, Nitschke I. Self-rating of satisfaction with dental appearance in an elderly German population. Int Dent J 2008;58(2):98-102. https://doi.org/10.1111/j.1875-595x.2008.tb00183.x

25. Silva GC, Castilhos ED, Masotti AS, Rodrigues SA. Dental esthetic self-perception of Brazilian dental students. RSBO 2012;9(4):375-81.

26. Bilal R. Self-perception and satisfaction with dental esthetics in dental students of Qassim region of Saudi Arabia. Pak Oral Dent J 2016;36(3):399-403.

27. Strajnić L, Bulatović D, Stančić I, Živković R. Self-perception and satisfaction with dental appearance and aesthetics with respect to patients' age, gender, and level of education. Srp Arh Celok Lek 2016;144(11-12):580-9.

28. Al-Saleh S, Abu-Raisi S, Almajed N, Bukhary F. Esthetic self-perception of smiles among a group of dental students. Int J Esthet Dent 2018;13:220-30.

29. Armalaite J, Jarutiene M, Vasiliauskas A, Sidlauskas A, Svalkauskiene V, Sidlauskas M, et al. Smile aesthetics as perceived by dental students: A cross-sectional study. BMC Oral Health 2018;18(1):225. https://doi.org/10.1186/s12903-018-0673-5

30. Wolfart S, Quaas AC, Freitag S, Kropp P, Gerber WD, Kern M. Subjective and objective perception of upper incisors. J Oral Rehabil 2006;33(7):489-95. https://doi.org/10.1111/j.1365-2842.2005.01581.x

31. Alkhatib MN, Holt R, Bedi R. Age and perception of dental appearance and tooth colour. Gerodontology 2005;22(1):32-6 https://doi.org/10.1111/j.1741-2358.2004.00045.x

32. Stefanac SJ, Nesbit SP. Diagnosis and Treatment Planning in Dentistry. $3^{\text {rd }}$ ed. St. Louis: Elsevier; 2017.

33. Al-Zarea BK. Satisfaction with appearance and the desired treatment to improve aesthetics. Int J Dent 2013;2013:912368. https://doi.org/10.1155/2013/912368

34. Larsson P. Methodological studies of orofacial aesthetics, orofacial function and oral health-related quality of life. Swed Dent J 2010;204:11-98.
35. Kershaw S, Newton JT, Williams DM. The influence of tooth colour on the perceptions of personal characteristics among female dental patients: Comparisons of unmodified, decayed and 'whitened' teeth. Br Dent J 2008;204(5):E9; discussion 256-7 https://doi.org/10.1038/bdj.2008.134

36. El Mourad AM, Al Shamrani A, Al Mohaimeed M, Al Sougi S, Al Ghanem S, Al Manie W. Self-perception of dental esthetics among dental students at King Saud University and their desired treatment. Int J Dent 2021;2021:6671112. https://doi.org/10.1155/2021/6671112

37. Althagafi N. Esthetic smile perception among dental students at different educational levels. Clin Cosmet Investig Dent 2021;13:163-72. https://doi.org/10.2147/CCIDE.S304216

38. Vieira I, Vieira-Junior WF, Pauli MC, Theobaldo JD, Aguiar FH, Lima DA, Leonardi GR. Effect of in-office bleaching gels with calcium or fluoride on color, roughness, and enamel microhardness. J Clin Exp Dent 2020;12(2):e116-22. https://doi.org/10.4317/jced.56006

39. Ashley M, Lamb DJ, Ellis B. Defects of dental appearance assessed by patient and dental student groups. J Oral Rehabil 2001;28:1116-21. https://doi.org/10.1046/j.1365-2842.2001.00838.x

40. Taibah SM, Al-Hummayani FM. Agreement and association between normative and subjective orthodontic treatment need using the index of orthodontic treatment need. J Orthod Sci 2019;8:1. https://doi.org/10.4103/jos.JOS_87_18

41. Neely ML, Miller R, Rich SE, Will LA, Wright WG, Jones JA. Effect of malocclusion on adults seeking orthodontic treatment. Am J Orthod Dentofacial Orthop 2017;152(6):778-87. https://doi.org/10.1016/j.ajodo.2017.04.023

42. Nayak UA, Winnier J, Rupesh S. The relationship of a dental aesthetic index with dental appearance, smile and desire for orthodontic correction. J Clin Pediatr Dent 2009;2:6-12.

https://doi.org/10.5005/jp-journals-10005-1023

43. Saliha Fn, Lindstenb R, Bågesundc M. Perception of orthodontic treatment need among Swedish children, adolescents and young adults Acta Odontol Scand 2017;75(6):407-12.

https://doi.org/10.1080/00016357.2017.1326062

44. Feldens CA, Nakamura EK, Tessarollo FR, Closs LQ. Desire for orthodontic treatment and associated factors among adolescents in Southern Brazil. Angle Orthod 2015;85(2):224-32.

https://doi.org/10.2319/021014-105.1

45. Zhang M, McGrath C, Hägg U. The impact of malocclusion and its treatment on quality of life: A literature review. Int J Paediatr Dent 2006;16(6):381-7. https://doi.org/10.1111/j.1365-263X.2006.00768.x

46. Kiyak HA. Does orthodontic treatment affect patients' quality of life? J Dent Educ 2008;72(8):886-94.

47. Asgari I, Ahmady AE, Yadegarfar G, Eslamipour F. Evaluation of orthodontic treatment need by patient-based methods compared with a normative method. Dent Res $J$ (Isfahan) 2013;10(5):636匹42.

48. Gürel G, Paolucci B, lliev G, Filtchev D, Schayder A. The fifth dimension in esthetic dentistry. Int J Esthet Dent 2021;16(1):10-32.

49. De Angelis P, Gasparini G, Rella E, De Angelis S, Grippaudo C, D'Addona A, et al. Patient satisfaction with implant-supported monolithic and partially veneered zirconia restorations. Biomed Res Int 2021;2021:6692939.

https://doi.org/10.1155/2021/6692939

50. Jreige CS, Kimura RN, Segundo ÂR, Coachman C, Sesma N. Esthetic treatment planning with digital animation of the smile dynamics: A technique to create a 4-dimensional virtual patient. [published online ahead of print, $2021 \mathrm{Feb} 9$ ]. J Prosthet Dent. 2021;S0022-3913(20)30600-4. doi:10.1016/j.prosdent.2020.10.015

51. Fiorillo L. Oral health: The first step to well-being. Medicina (Kaunas) 2019;55(10):676. https://doi.org/10.3390/medicina55100676

52. Meira TM, Prestes J, Gasparello GG, Antelo OM, Pithon MM, Tanaka OM. The effects of images posted to social media by orthodontists on public perception of professional credibility and willingness to become a client. Prog Orthod 2021;22(1):7. https://doi.org/10.1186/s40510-021-00353-9

53. Dannemand K, Ozhayat EB. Recognition of patient-reported impairment in oral aesthetics J Oral Rehabil 2014;41(9):692-9. https://doi.org/10.1111/joor.12183

54. Lajnert V, Pavičić DK, Gržić R, Kovač Z, Pahor D, Kuis D, et al. Influences of age and maxillary anterior teeth status on patient's satisfaction with dental appearance and tooth colour. Gerodontology 2012;29(2):e674-9.

https://doi.org/10.1111/j.1741-2358.2011.00543.x

55. Mehl C, Wolfart S, Vollrath O, Wenz HJ, Kern M. Perception of dental esthetics in different cultures. Int J Prosthodont 2014;27(6):523-9.

https://doi.org/10.11607/ijp.3908 